\title{
Processo Resolutivo do Jogo Computadorizado Tetris: Análise Microgenética
}

\author{
Miriam Schifferli Hoff ${ }^{123}$ \\ Solange Muglia Wechsler \\ Pontificia Universidade Católica de Campinas
}

\begin{abstract}
Resumo
Com abordagem piagetiana, efetuou-se uma análise microgenética da resolução do Tetris por 2 universitárias. Individual e filmado, o procedimento incluiu pré-avaliação de possiveis, sessões do Tetris e auto-avaliações. Relata-se aqui a evolução da Participante-1 (P1), cuja amplitude permitiu maior compreensão do processo resolutivo. Na pré-avaliação, P1 revelou pensamento formal. Seu domínio do Tetris evidenciou melhorias na constituição de possíveis — estratégias, soluções e compreensão do jogo — subordinadas à dinâmica da equilibração e pensamento dialético, com mútuas influências entre suas representações do jogo, do fazer e dos resultados. Exibiu soluções finais em Nível-III, mas possíveis iniciais e erros mais elementares do que hipotetizado para um sujeito com pensamento operacional. Inversamente, criou interdependências mais abrangentes e complexas do que o previsto. Ao resolver o Tetris, P1 como que refez o percurso da evolução cognitiva, com progresso projetado até o patamar de suas estruturas cognitivas. Palavras-chave: Possíveis e pensamento dialético; microgêneses cognitivas; jogo computadorizado; universitárias.
\end{abstract}

The Computer Game Tetris' Solution: A Micro Genetic Analysis

\begin{abstract}
A microgenetic analysis of the Tetris' solution by two female college students was carried out with a Piagetian approach. The individual and videotaped procedure included pre-evaluation of possibilities, Tetris sessions and self-evaluations. One focuses on Participant-1 (P1), whose evolution provided more understanding about the solution process. In the pre-evaluation, P1 revealed a formal thought. Her Tetris' domain showed improvements in the construction of possibilities — game understanding, strategies and solutions - subordinated to the equilibration and dialectic thought, with mutual influences between her Tetris', resolution's and results' representations. P1 exhibited III-Level final solutions, but more elementary initial possibilities and mistakes than hypothesized to a person with formal thought. In contrast, she constructed more encompassing and complex interdependences than predicted. When solving the Tetris, it was as if P1 were remaking the cognitive evolution course, with progress projected on her top-level cognitive structures.

Keywords: Possibilities and dialectic thought; cognitive microgenesis; computer game; college students.
\end{abstract}

Com a difusão do computador junto à classe média brasileira nos anos 1990 (Setton, Castro, Vettorazzo, Prandini \& Garzaro,1998), jogos computadorizados tornaram-se parte do cotidiano de muitas crianças e adolescentes, constituindo uma das suas atividades mais freqüentes com o computador (Hoff \& Wechsler, 2002).

Tais jogos comportam espaço lúdico e objetos virtuais exibidos em uma tela de TV ou no monitor de um computador, com imagens animadas e sonorizadas nas quais o jogador interfere. Integrados por eventos rápidos, móveis e simultâneos, demandam coordenação de variáveis interagentes e, para tanto, habilidades de representação espacial dinâmica e atenção visual distribuída (Greenfield,

\footnotetext{
${ }^{1}$ Parte da Tese de Doutorado da primeira autora, sob a orientação da segunda, apresentada em 2001 ao Programa de Pós-Graduação em Psicologia do Instituto de Psicologia e Fonoaudiologia da PUC-Campinas, SP.

${ }^{2}$ Especiais agradecimentos às universitárias participantes do estudo e à PUCCampinas, pelo apoio institucional e financeiro.

${ }^{3}$ Endereço para correspondência: Faculdade de Psicologia, Campus-II, Av. João Boyd Dunlop, s/no 13059 900, Jardim Ipaussurama, Campinas, SP. Fone: (19)3729-8442, Fax: (19)3729-8665.E-mail:mhoff@uol.com.br
}

1984/1988). Com um contexto de aprendizagem indutiva, a prática de jogos de computador favorece habilidades de planejar, de gerar e avaliar hipóteses (Johnson, 1987; Mandinach, 1984), contribuindo para flexibilidade cognitiva e criatividade (Doolittle, 1995). De ensaios-erros, o jogador evolui para ações planejadas e sistematizadas, frutos de heurísticas e de processos metacognitivos, daí resultando compreensão e domínio do jogo (Greenfield, 1984/1988; Horak, 1990).

Para Rieber (1996), os jogos de computador envolvem aprendizagem auto-regulada: a motivação é intrínseca ao jogar e o sujeito é ativo - tem metas, planeja, avalia e controla suas ações. Esta noção de aprendizagem guarda parentesco com concepções piagetianas, pois, ao explicá-la em termos de assimilações e acomodações, de conflitos cognitivos, abstrações reflexionantes e auto-regulação, Rieber conflui para o processo da equilibração majorante (Piaget, 1975/ 1976, 1977/1995).

Por conjugarem solução de problemas e criatividade, jogos de regra integraram muitos estudos piagetianos sobre o funcionamento cognitivo na elaboração de soluções e sobre 
os mecanismos subjacentes à criação de possiveis (Piaget, 1976/ 1992, 1974/1978a, 1974/ 1978b, 1981/1985, 1983/1986).

Se alguém decide resolver um jogo de regra, então o desafio gerou uma perturbação que vai mobilizar o processo de equilibração (Piaget, 1975/1976). Porém, a solução não é imediata; surge por etapas que avançam segundo a compreensão do jogo, pois sem esta o sujeito vai se ater a ensaios-erros e a pouco êxito (Macedo, 1980). Para tanto, a tomada de consciência (Piaget 1975/1976) se torna condição da criação de novas estratégias, traduzindo-se na avaliação das ações efetuadas, do como os objetos foram usados e dos resultados. Ela significa conceituar estes aspectos e manipulá-los simbolicamente, com base em retroações e antecipações. Retroagir é voltar ao ponto inicial, mas, feita uma jogada, isto só é possível no plano de representações, pelo confronto resultado-objetivo-ações, do qual pode advir abertura para novas ações e correção das iniciais. Este vai e volta tende a suscitar antecipações — projeção, em pensamento, de ações futuras ainda não materializadas e que evitam erros. Assim, a resolução de um jogo de regras demanda reconstruções no plano representacional, que é superior ao das ações materiais (fazer) e supõe, portanto, abstrações reflexionantes (Piaget, 1974/1978a, 1974/1978b, 1977/1995).

Ainda, elaborar novas estratégias é considerar outras formas de ação, outros possíveis, conjugados ao necessário (Piaget, 1976/1992, 1981/1985, 1983/1986). Possibilidades e necessidades não são, porém, fatos externos simplesmente descobertos; são produtos de atividade mental do sujeito (Piaget, 1983/1986). Uma ação ou um resultado se torna um possível quando concebidos como consistentes com uma meta e compreendidos em suas condições de efetivação (Piaget, 1976/1992). Solidariamente, "o necessário... repousa num modelo que propõe uma razão". (Piaget, 1983/1986, p. 121). Assim, o confronto resultado-objetivo-ações realizadas é mediado pelas concepções do sujeito sobre o jogo e sua solução, implicando uma resolução no contexto de construções e de pensamento dialéticos, com seu duplo controle ascendentedescendente (Piaget, 1980/1996).

Frente ao jogo e suas instruções, o jogador formula um modelo inicial sobre seu objetivo e funcionamento. Tal modelo exerce um controle descendente que se desdobra em ações planejadas (guiadas por antecipações) e conduz a certos resultados (Inhelder \& Caprona, 1992/1996a). A interpretação das ações e de seus efeitos leva a um controle ascendente que atua na consolidação ou reformulação das estratégias e das concepções (modelo) sobre o jogo. Assim, configura-se a circularidade dialética com seu ir e vir entre antecipações e retroações corretivas, da qual resultam novas interdependências, não diretamente entre ações e resultados, mas entre as significações (representações) que o sujeito lhes atribui segundo o modelo atuante. Neste processo, o controle ascendente responde pelos possíveis (novos conceitos, formas de ação e resultados) e o descendente, pelo necessário (integração em novas totalidades), a conjugação de ambos implicando a interdependência dos próprios mecanismos de assimilação e acomodação dentro da dinâmica da equilibração (Inhelder \& Caprona, 1992/ 1996a; Piaget, 1980/1996).

Pesquisas brasileiras de base piagetiana têm revelado contribuições de jogos de regras na promoção do raciocínio de crianças (Brenelli, 1997), do pensamento lógico-dialético (Macedo, 1993; Macedo \& Barone, 1997) e de noções aritmético-operatórias (Brenelli, 1996). Outras têm avaliado o pensamento e a criação de possíveis na solução de jogos de regras por pré-escolares e alunos do ensino médio (Abreu, 1996; Ortega, Alves \& Rossetti, 1992), crianças com necessidades especiais (Santos, 1998) e universitários (Queiroz, 1995). Mas não foi localizada nenhuma pesquisa sobre possíveis e pensamento dialético em jogos computadorizados. Esta condição, as evidências acima e a atratividade destes jogos para crianças e adolescentes sustentaram o objetivo de estudar-se a elaboração de possíveis e o pensamento dialético no processo resolutivo de um jogo computadorizado.

Esta meta implicou examinar mudanças procedurais e conceituais durante o processo resolutivo do jogo e, através de indicadores quantitativos, dimensionar avanços de uma sessão de jogo a outra. Assim, configurou-se uma análise microgenética, aqui relatada para um dos dois participantes investigados, e uma análise quantitativa (alvo de outro artigo).

Por se tratar de estudo inicial sobre resolução de um jogo de computador, escolheu-se o jogo Tetris, mais elementar em relação a preferências identificadas entre adolescentes (Hoff \& Wechsler, 2002), mas muito dinâmico. A exigência de observação dos jogadores em muitas sessões de jogo, com vindas à Universidade que sediou a pesquisa, levou ao estudo de universitários. Evidências de mais prática e conhecimento pelo sexo masculino - em nosso meio (Hoff \& Wechsler, 2002) e na literatura internacional (Hoff, 2001) — aliadas à necessidade de sujeitos pouco experientes nestes jogos e que desconhecessem o Tetris, levaram à seleção de participantes do sexo feminino.

\section{Estudo Microgenético da Resolução do Tetris: Hipóteses e Fundamentos}

A clarificação das hipóteses demanda prévia descrição do jogo e da tarefa. Usou-se o Tetris Emlith 3.01E (Emura, 1996/1993), em um CD (CDExpert, 1996), na forma com 7 peças. A Figura 1 mostra estas peças e suas 19 posições por rotações em sentido horário, a área de jogo, o placar e, à esquerda, a peça seguinte do jogo. Ativado o Tetris, uma 


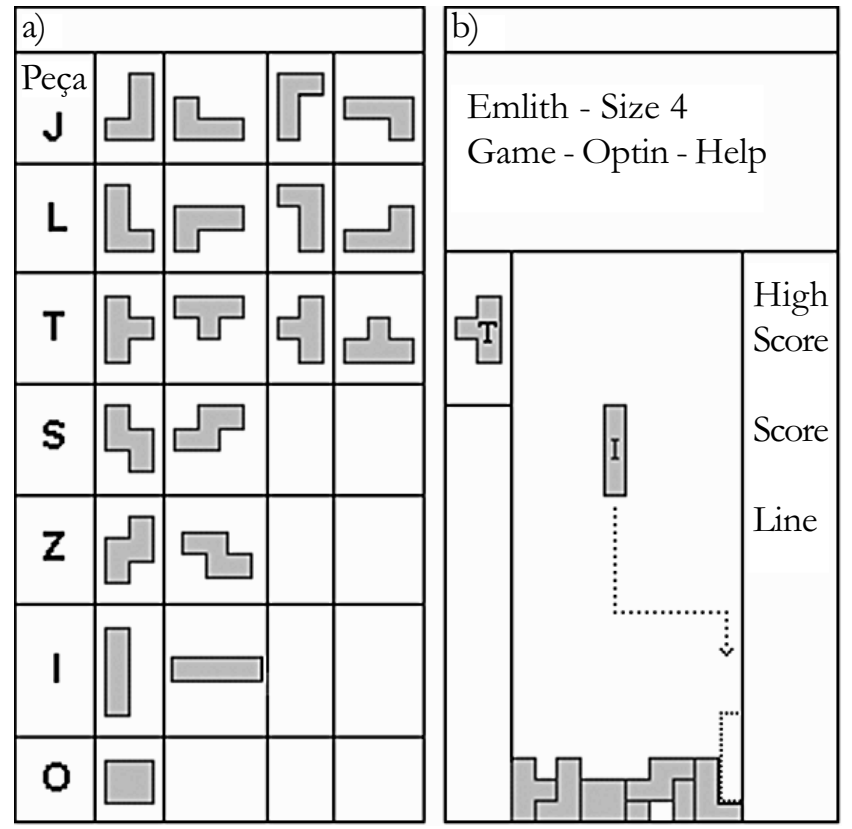

a) Conjunto das 7 figuras (peças de 4 elementos) e suas 19 posições por rotação em sentido horário

b) Área de jogo do Tetris-Emlith: construção parcial e $1^{\text {a }}$ linha incompleta; peça ativa (I), próxima peça (T) e placar; exemplo de um deslocamento para encaixe da peça $\mathrm{I}$.

Figura 1. Tetris-Emlith, 3.01E, Size 4.

peça é liberada por vez e, automaticamente, vai descendo. Por meio de certas teclas, pode-se movê-la à direita ou esquerda; para baixo, rápida ou lentamente; fazer rotações e pausar o jogo. A meta é formar uma linha completa ou, simultaneamente, duas, três ou quatro, o que gera pontos diferentes (1, 5, 10 e 20). Cada linha completa desaparece e libera mais área. Um jogo acaba quando sua área ficar preenchida por linhas incompletas — não há tempo limite. Quanto menos jogos realizados num período, maiores o tempo com cada um e a pontuação obtida. A velocidade da peça ativa cresce dentro de um jogo e de um para outro. A entrada de peças é aleatória, impedindo memorizar suas seqüências. Mas, o fato de uma delas não aparecer já há algum tempo permite antecipá-la para um futuro próximo. Esta previsão e a observação da próxima peça a entrar no jogo podem originar planos de ação.

Cada objetivo - linha unitária ou composta — supõe ações guiadas por modelos mentais diferentes. A uma linha corresponde a representação de um retângulo com altura de um quadradinho; a uma dupla, um retângulo com altura de dois quadradinhos, etc. Guiada pelo objetivo, que delimita o necessário e os possíveis cabíveis, a tarefa pede contínua criação de interdependências. Mas, as mesmas ações e resultados - encaixe e fragmento de construção — podem ter diferentes significados segundo sejam parte de linha unitária ou de linhas simultâneas, isto é, segundo os objetivos do sujeito. Tal idéia equivale ao núcleo da noção piagetiana de construções dialéticas: estabelecer interdependências por implicações entre os significados das ações (Piaget, 1980/ 1996). Foi nesta perspectiva de resolução do jogo que se supôs o Tetris envolvendo construções e pensamento dialéticos.

Piaget (1976/1992,1981/1985,1983/1986) identificou três níveis evolutivos na criação de possíveis e hipotetizou-os correspondentes aos estágios pré-operacional, das operações concretas e das formais, respectivamente: I- Poucos possíveis, por analogias com situações constatadas, sucessivamente criados na ação e não inferidos (possivivis analógicos); II- Possíveis simultâneos, por conjugação das analogias: co-possiveis concretos, antecipados, mas restritos àqueles que o sujeito realiza e em número limitado. Ao final do estágio das operações concretas, surgem os co-possiveis abstratos, antecipados em maior número do que os concretizados, que são descritos como alguns dos concebidos; III- Co-possiveis abstratos quaisquer e ilimitados (quando pertinente). Em problemas com soluções restritas ou solução única, criação de co-possivel (eis) exigivel (eis) em função de um necessário que, antecipado, resulta em convergência para determinado(s) resultado(s).

$\mathrm{Na}$ resolução de jogos de regras, Macedo $(1993,1994)$ identificou três níveis de erros: I- Problema não solucionado e, até, nem compreendido. Ocorrem justaposições (ações sucessivas, não articuladas como partes de um todo) e sincretismo (sínteses distorcidas, por consideração a aspectos parciais, desconectados). Não há consciência do erro que, então, não afeta a conduta. II- A solução é empírica (ensaioerro). O erro se torna um observável e, assim, um problema, mas só depois de ocorrido; logo, há mais retroações para superação do erro do que antecipações. III- Compreensão ampla do problema. O erro se torna um possível dentre outros (parte de um sistema de ações) e passa a ser levado em conta, com evolução das retroações para antecipações (ações mentais que evitam erros).

Estes níveis evolutivos foram identificados em crianças e adolescentes. No gradativo domínio de um jogo de computador por universitárias e prevendo-se delas pensamento no mínimo operacional concreto, pareceram improváveis condutas elementares esperadas de crianças. Assim, o estudo teve por hipóteses: 1) Ausência de possíveis em Nível-I; co-possíveis concretos (Nível-II), evoluindo para co-possíveis abstratos/exigíveis (Nível-III). 2) Erros de Níveis-II/III: soluções iniciais empíricas (ensaio-erro, retroações corretivas), avançando para antecipações/ inferências e pré-correção de erros. Ausência de erros em Nível-I (justaposições, sincretismo). 3) Para as construções dialéticas, hipotetizou-se interdependências com abrangência crescente e planejamento de ações progressivamente mais 
complexo: a) inter-objetos (peças do Tetris): descoberta das relações possíveis entre as peças levando à composição, não necessariamente intencional, de segmentos de linha; b) interdependências partes-todo: articulação entre possíveis encaixes das peças com intenção de compor uma linha completa (pelo menos) e, portanto, com consideração à construção; c) interdependência presente-futuro próximo: consideração simultânea da peça atual em relação com a construção, com a peça futura visível e com o objetivo de composição de uma linha completa, pelo menos.

\section{Método}

Pela natureza do problema, efetuou-se uma análise microgenética cuja característica é focar o processo gerador de mudanças de cunho desenvolvimental (Branco, 1998; Inhelder \& Cellérier, 1992/1996; Meira, 1994). Esta análise apoiou-se em videogravação para a observação, coleta e registro de dados.

\section{Participantes}

Participaram 2 universitárias de $1^{\text {a }}$ série do curso de Psicologia da Pontifícia Universidade Católica de Campinas. Selecionadas dentre as 56 alunas da classe, além de disponibilidade para sessões diárias de jogo e consentimento para sua filmagem, estas alunas tinham pouca experiência com jogos computadorizados e desconheciam o Tetris.

\section{Instrumentos e Equipamentos}

Além do Tetris, foram utilizados: quatro provas de Piaget (1981/1985) que envolvem relações entre formas e espaço - construção de eqüidistâncias, formas possíveis de um objeto parcialmente escondido, maior construção possível com os mesmos objetos e possível dedutível; um computador e um monitor colorido; uma filmadora e fitas VHS; uma TV e um videocassete.

\section{Procedimentos para a Coleta de Dados}

A coleta abrangeu pré-avaliação de possíveis, 9 sessões de jogo (perto de $1 \mathrm{~h}$ cada) e 3 auto-avaliações de desempenho (AA). Todas atividades foram individuais e filmadas, mas com preservação da identidade das participantes: a filmadora foi acoplada à TV para filmagem e transmissão simultânea, acompanhando-se os jogos sem um observador ao lado da jogadora. Foram 5 dias de atividades, em dois períodos (perto de 1h, cada) com intervalo de meia hora: 1) avaliação de possíveis; $1^{a}$ sessão de jogo e $1^{a} \mathrm{AA}$; 2) $2^{\mathrm{a}}$ e $3^{\mathrm{a}}$ sessões; 3) $2^{\mathrm{a}} \mathrm{AA}, 4^{\mathrm{a}}$ e $5^{\mathrm{a}}$ sessões; 4) $6^{a}$ e $7^{a}$ sessões; 5) $8^{a}$ sessão, $3^{a}$ AA e $9^{a}$ sessão.

\section{Avaliação de Possíveis}

Apreciou a elaboração de possíveis pelas participantes e o seu nível de pensamento antes das sessões de jogo, tendo fornecido parâmetros para análise da resolução do Tetris. Já referidas, as provas foram aplicadas conforme Piaget (1981/ 1985).

\section{Sessões do Jogo Tetris}

Ao início da $1^{a}$ sessão, um jogo foi acessado e pausado. Com a imagem imobilizada e mostrando apenas duas peças (ativa e seguinte), foram dadas as instruções do jogo, com o teor apresentado na descrição do Tetris. A jogadora testou as teclas e foi solicitada a repetir as instruções. Com um novo jogo, deu-se início às suas jogadas, com a pesquisadora acompanhando o desenrolar de cada sessão pela TV.

\section{Auto-avaliações do Desempenho no Tetris}

Visaram cotejar interdependências criadas nos jogos (estratégias e resultados) e no discurso (expressão da compreensão). A 1ª AA incluiu as questões: “1) para explicar como funciona o jogo, que instruçoes você daria? 2) como explicaria o modo de agir para obter muitos pontos? 3) de 0 a 10, que nota daria à sua $1^{a}$ sessão e por quê? acha necessário alterar seu modo de jogar?". Pelo intervalo de 3 dias entre $3^{a}$ e $4^{a}$ sessões (vestibulares na Universidade), na $2^{\mathrm{a}} \mathrm{AA}$ pediu-se a descrição do funcionamento do jogo, explorando-se as respostas para resgatar regras omitidas. $\mathrm{Na} 3^{\mathrm{a}} \mathrm{AA}$, as jogadoras foram solicitadas a rever a nota auto-atribuída à $1^{\text {a }}$ sessão e justificar se a alterariam; a atribuir-se uma nota pelo desempenho atual, justificando-a; a assistir trechos da suas $1^{\mathrm{a}}$ e $8^{\mathrm{a}}$ sessões, indicando jogadas que fariam diferente e por quê.

\section{Procedimentos para a Análise Microgenética da Resolução do Tetris}

Incluíram: a) Exame repetido das fitas; b) Transcrição figurativa dos dados: ponto a ponto de cada jogo, a imagem no vídeo era congelada e desenhada em papel; c) Análise das fitas e das transcrições para identificação dos momentos, natureza e evolução das alterações nas estratégias, nos resultados e na compreensão do Tetris; d) Descrição interpretativa de segmentos prototípicos em forma verbal e gráfica, esta agora em versão computadorizada. A Figura 1, já apresentada, é um exemplo e, como as demais figuras adiante, consiste em uma tabela gerada com o Editor de Textos Word 2000.

\section{Resultados}

\section{Participante 1: Descrição e Discussão Provas de Possíveis}

A participante-1 (P1) exibiu certo tateio inicial e não soluções apenas inferidas. Mas, ao longo de cada prova, atingiu o plano de possíveis abstratos e quaisquer, dedutíveis e exigíveis. Com argumentos formais consistentes, articulou 
necessidades e possibilidades, tanto para soluções concretizadas como hipotéticas. No todo, revelou pensamento formal, hipotético-dedutivo, e foi classificada em Nível-III pelos critérios de Piaget (1981/1985).

\section{Análise Microgenética da Resolução do Tetris}

No todo das sessões, P1 reuniu 9,96 h de jogo (31 completos e 2 incompletos), fez 1433 linhas e 2752 pontos.

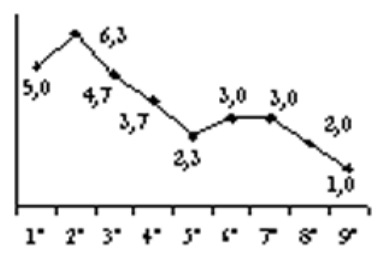

$\mathrm{N}^{\mathrm{o}}$ de jogos

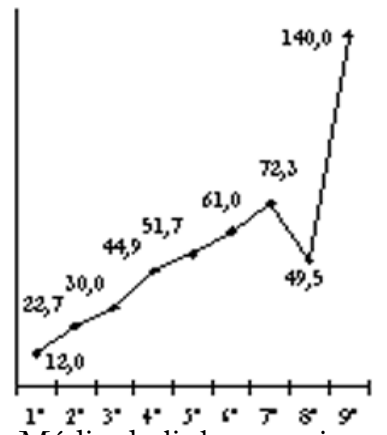

Média de linhas por jogo

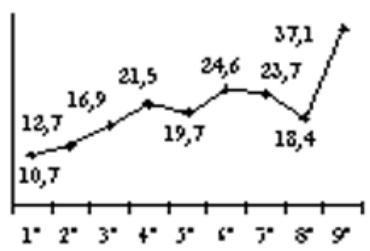

Tempos médios de jogo

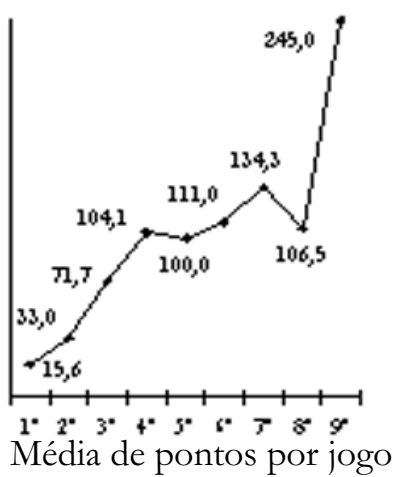

Figura 2. Indicadores de desempenho por jogo em cada sessão do Tetris.

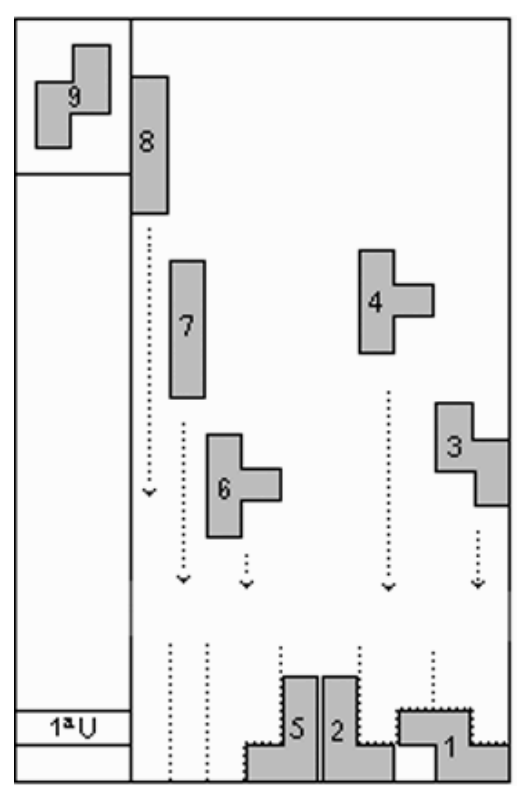

a) Encaixes das peças 1-8; criação da $1^{\text {a }}$ unitária $(\mathrm{U})$

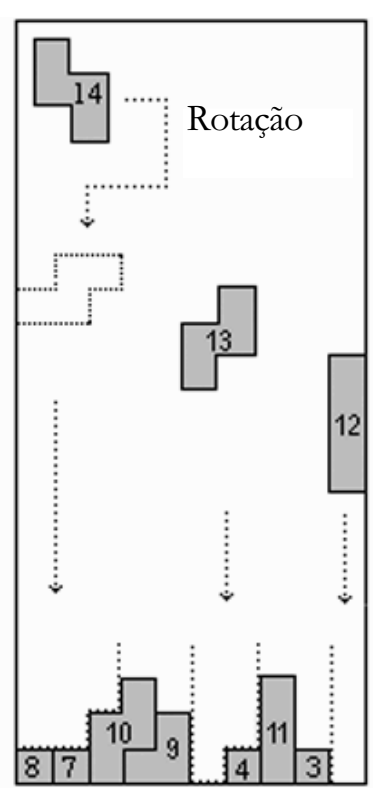

b) Formação da $4^{a} \mathrm{U}$; rotação e encaixe da S-14
Sessão 1-jogo 1: $1^{\text {a }}$ parte
Como mostra a Figura 2, teve um progresso grande e relativamente contínuo, segundo a relação inversa esperada: ao longo das sessões, queda no número de jogos com aumento nas suas médias de duração, de linhas construídas e de pontos. Esta relação espelhou uma tríplice evolução: a) aumento na constituição de possíveis - encaixes e linhas completas; b) maior rapidez nas construções; c) avanço de linhas unitárias para as compostas, com mais interdependências simultâneas e, assim, possíveis mais complexos. Para clarificar esta evolução, o processo resolutivo de $\mathrm{P} 1$ foi descrito resumindo-se suas principais mudanças microgenéticas e seu significado cognitivo.

\section{Condutas Resolutivas Iniciais}

No jogo 1-sessão 1 houve dois modos de resolução. No primeiro (18 peças iniciais), a maioria das peças foi encaixada na posição de ingresso, condição esta propiciada pela entrada aleatória de peças e mostrada na Figura 3: sucessivamente, o contorno da construção foi demarcando espaço fácil de identificar como correspondente à base da peça ativa na posição de entrada. Sem demanda de rotações ou de coordenação entre cada peça e a subseqüente (interdependência), sem mediação de antecipações, estes encaixes se configuraram possíveis analógicos (Nível-I).

Iniciada com a peça 19, a segunda parte marcou-se por maior velocidade do jogo e por exigências de rotação. Ocorreram interdependências adequadas com peças em posições diferentes das de ingresso (co-possíveis

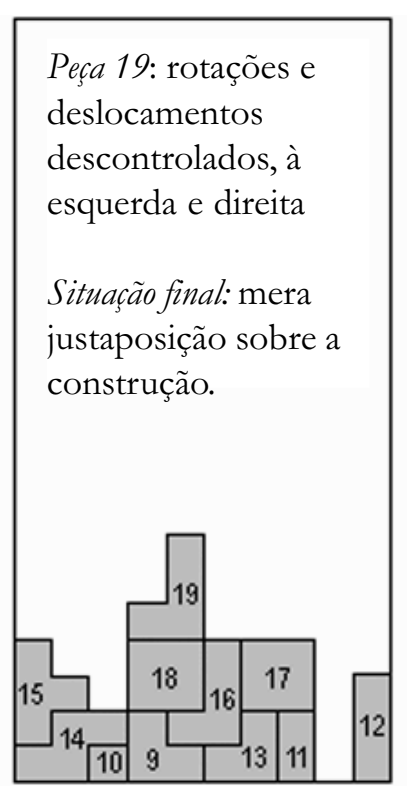

c) Justaposição da J-19; $2^{a}$ parte/jogo-1 iniciada

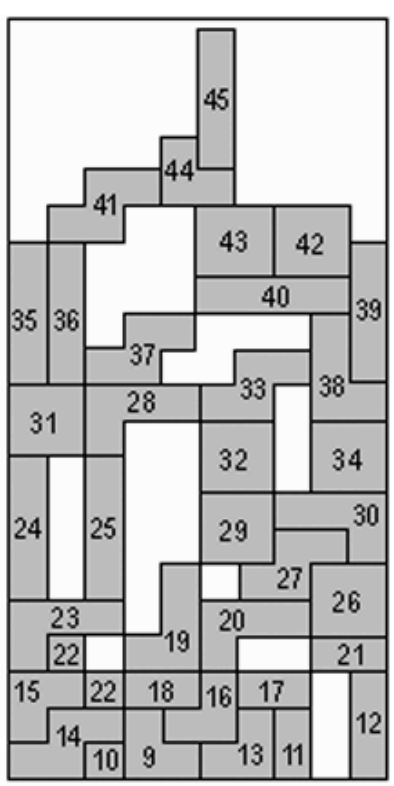

d) Justaposição de peças e construção sincrética
Sessão 1- jogo 1: $2^{\mathrm{a}}$ parte

Figura 3. Jogo- 1 da sessão-1: possíveis analógicos, justaposição de peças e configuração sincrética da construção. 
concretos), mas mais restritas a peças isoladas. No todo, sobressaiu uma sucessão de linhas incompletas decorrentes de justaposições, com a maioria das peças apenas colocadas lado a lado. Invés da sua síntese em linhas completas, resultou uma grande construção sincrética (erros de Nível-I) (Figura 3 c e 3d). Com tais elaborações e erros, inesperados num sujeito com pensamento formal, as duas primeiras hipóteses do estudo foram rejeitadas. Possíveis analógicos restringiramse a este primeiro jogo, mas em todos os demais ocorreram justaposições e construções sincréticas, embora ligadas a condições diferentes — o que será posteriormente retomado.

\section{Possíveis com as Peças em Diferentes Posições e Correspondências Peças-Espaços}

Fazer encaixes com as 7 peças exigiu integrá-las em diferentes posições, ou seja, co-possíveis concretos (NívelII). Nas sessões 2-3, encaixes precisos das peças J, L, O e I já sugeriam antecipação das rotações necessárias. Com as dentadas T, Z e S houve tateios, rotações descontroladas ou justaposições, até a sessão-3. Mesmo assim, já na sessão1jogo 4, P1 avançou para possíveis abstratos: começou a posicionar a $1^{a}$ peça de um jogo mais no centro da base (Figura 4a). Uma vez que, além da peça ativa e construção, o único outro observável é a peça seguinte, a conduta implicou possíveis abstratos (Nível-III): abertura para encaixes em seus dois lados e espaço previsto para qualquer peça. Tratou-se de novo procedimento com antecipações mais amplas, cuja extensão para o transcurso de um jogo se deu apenas na sessão 5-jogo 2 (Figura 4b). Paralelamente, a consecução crescente de linhas e blocos, com peças bem articuladas, atestou a criação de possíveis exigíveis,

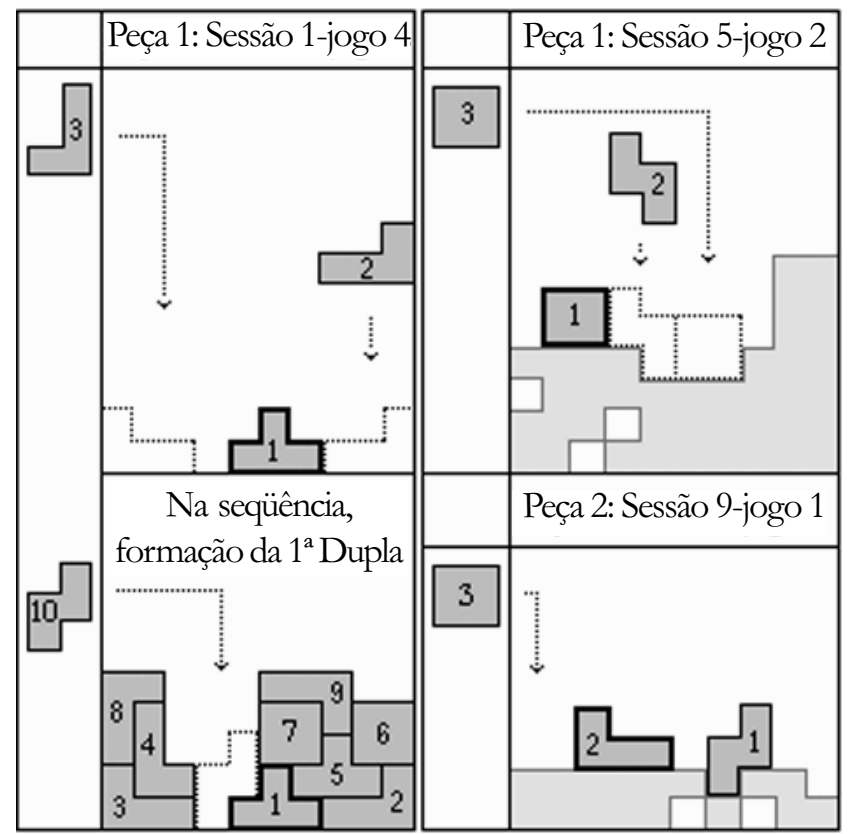

a) Peça inicial de um jogo posicionada com abertura para quaisquer encaixes.

b) Peça, no curso de um jogo, posicionada com abertura para quaisquer encaixes

Monobloco na base: construção na qual se insere o fragmento sob análise (recurso usado em outras figuras).

Figura 4. Possíveis abstratos no nível das peças.

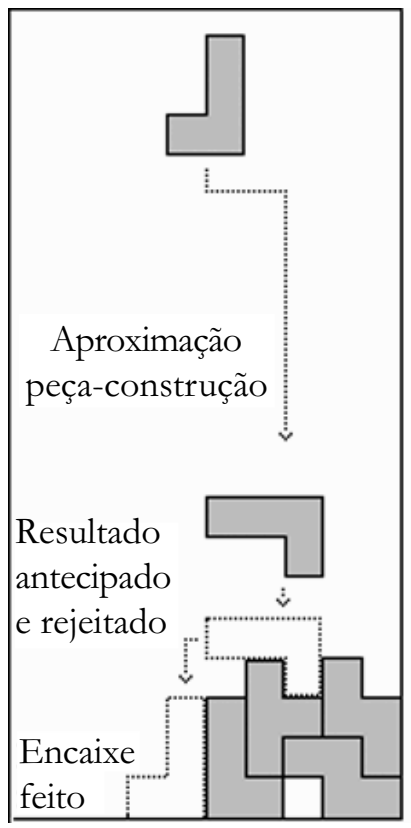

a) Aproximação peçaconstrução

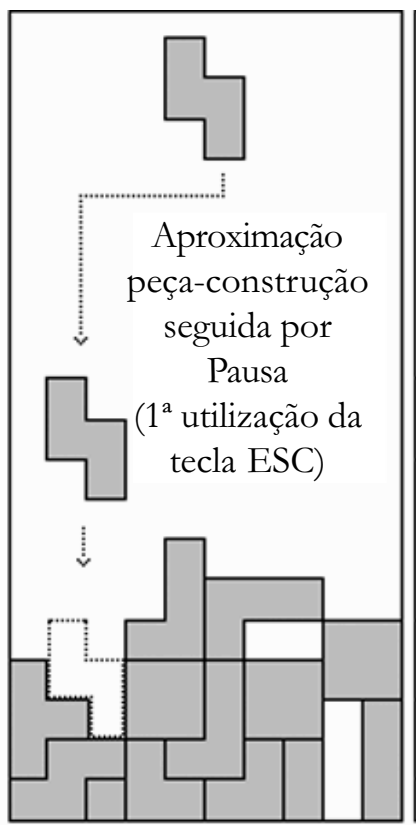

b) Aproximação peçaconstrução + pausa

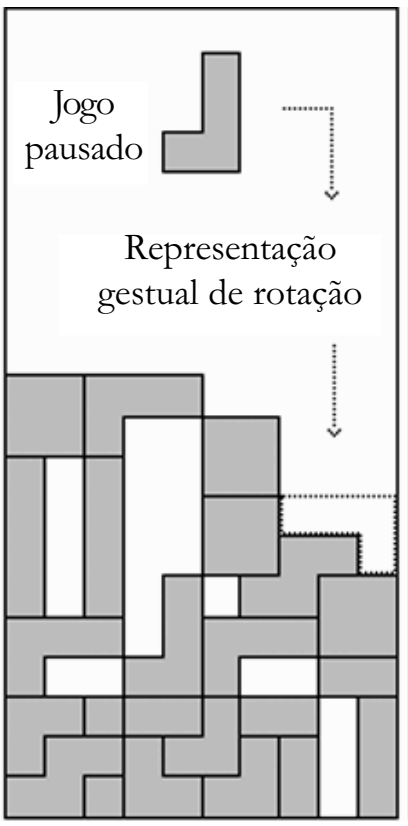

c) Pausa no jogo + rotação gestual

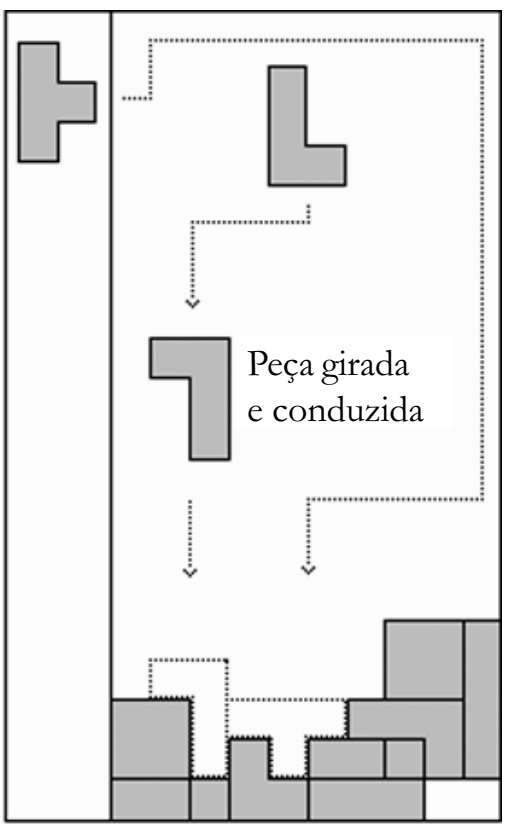

d) Pausa no jogo + representação mental

Figura 5. Constituição evolutiva da representação das correspondências peças-espaços. 
subordinados ao necessário no contexto integrado por objetivo-peça atual-peça seguinte-construção. Desta forma, tendo partido dos possíveis mais elementares, P1 reproduziu na sua resolução as várias categorias evolutivas da constituição de possíveis.

Tais avanços demandaram representações mentais das correspondências peças-espaços na construção, inferidas de esquemas de ação cuja evolução está retratada na Figura 5:

a) a peça ativa era aproximada da construção (confronto de observáveis); b) aproximação peça-espaço + pausa no jogo (antecipações favorecidas por observáveis imobilizados); c) pausa, logo após a entrada da peça + rotações simbólicas (gestuais); d) representação mental da correspondência peçaespaço (encaixes precisos, sem pausas ou gestos).

Aproximar peça-espaço e fazer pausas significaram ações para "fazerfalar o objeto" (Inhelder \& Caprona, 1992/1996a, p. 32), que favorecem abstrações empíricas e, assim, a descoberta de atributos de objetos (Piaget, 1977/1995). As rotações gestuais implicaram criar objetos para pensar símbolos materializados que simplificam a interpretação de um problema e o planejamento de ações (Inhelder \& Caprona, 1992/1996a; Saada-Robert, 1992/1996). Comuns em crianças, também o são em adolescentes e adultos (desenhos, diagramas e gestos), na solução de problemas físico-matemáticos e lógicos (Horak, 1990; Shama \& Dreyfus, 1994; Simon, 1982, citado em Inhelder \& Caprona, 1992/1996a, p. 36). Estas formas de conduta foram passos na evolução de P1 até representações mentais das correspondências peças-espaços, pela transição das abstrações empíricas para reflexionantes, com reconstrução das representações em nível mais abstrato (Piaget, 1977/1995). Surgidos no jogo 1-sessão 1, os esquemas (a), (b) e (c) evoluíram com o uso de pausas que, muito freqüente da sessão-3 em diante, assegurou análises e tomadas de consciência por parte de P1, bem como seu ajustamento à maior velocidade dos jogos.

Subjacente às articulações peças-posições, atuou a equilibração por regulações ativas (tomadas de consciência), por feedbacks positivos (encaixes corretos fortalecidos) e negativos (modificação de encaixes), o que se revelou no aumento de encaixes corretos, na consciência de P1 sobre erros (interjeições) e na redução destes. Tratou-se, ainda, das três formas da equilibração: na interação com peçasespaços-construção; na diferenciação dos encaixes de cada peça (equilibração horizontal); na sua integração em microsistemas, ou conjunto dos possíveis com cada peça (equilibração vertical) e destes como partes do sistema resolutivo (equilibração vertical numa totalidade maior). (Piaget, 1975/1976).

Fazer encaixes (interdependências parte-parte) não foi uma meta a ser dominada para, só depois, P1 buscar formar linhas completas (articulações partes-todo) como previam as hipóteses 3-a e 3-b. Desde o início foi um meio para formar linhas, o que implicou articulações peça-espaçoconstrução, com o controle descendente do modelo-diretriz (linha $=$ retângulo) delineando o necessário e guiando o fazer (Inhelder \& Caprona, 1992/ 1996b; Piaget, 1980/1996). Com regulações ativas, feed-backs positivos e negativos, configurou-se o controle ascendente dos encaixes e formação de linhas, com as ações logo se voltando para interdependências peça atual-seguinte-construção-objetivo.

Assim, a constituição de possíveis com as peças já evidenciou a solidariedade entre equilibração e a dialética das construções conceituais e executivas (Inhelder \& Cellérier, 1992/1996; Piaget, 1974/1978a, 1974/1978b, 1975/ 1976, 1980/1996). Uma vez que, já no ponto de partida, a constituição de interdependências foi mais abrangente do que o previsto, as hipóteses sobre estas construções dialéticas (3a, 3b, 3c) foram rejeitadas.

\section{Representações e Avaliação na Resolução do Tetris}

$\mathrm{O}$ avanço de $\mathrm{P} 1$ ligou-se, ainda, a procedimentos baseados em três modos de avaliação. O primeiro — antecipações que norteavam a criação de interdependências — revelouse na gradual composição de blocos de peças bem articuladas (Figura 4 já apresentada). O segundo consistiu em esquemas pré-corretivos que evitavam erros (Figura $5 \mathrm{a}$ ) ou que asseguravam a consecução de um objetivo mais complexo, a partir da avaliação de resultados previstos e reorientação do curso da ação (Figura 6). O terceiro modo se deu em

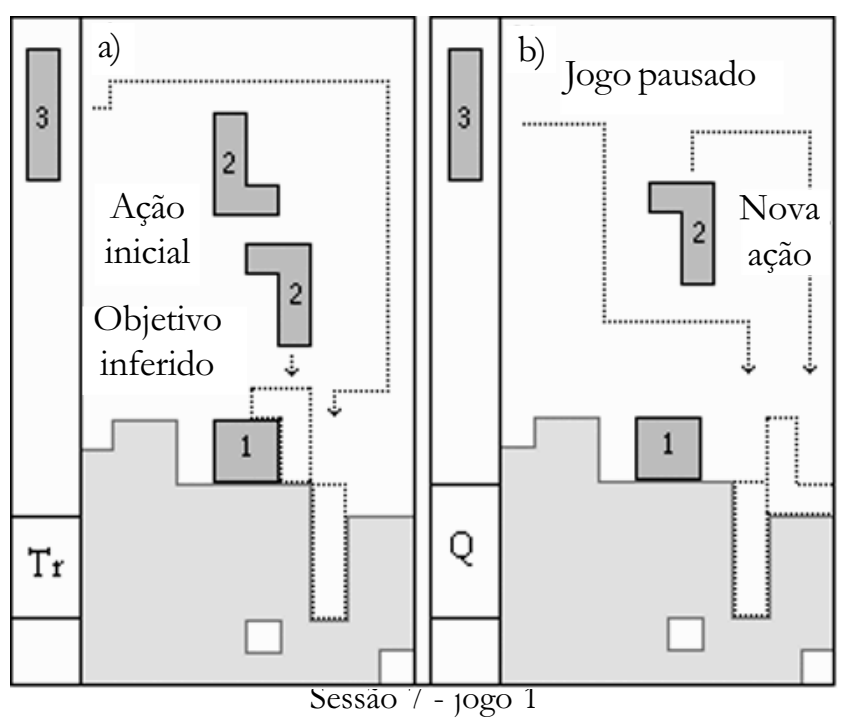

a) Plano/objetivo inicial: uma tripla, com I-3

b) Objetivo efetivado: quádrupla, por rearticulação entre peça atual - seguinte - totalidade

Figura 6. Reorientação de um objetivo por antecipações pré-corretivas. 
esquemas compensatórios (retroações corretivas), derivados de descoberta da possibilidade de ainda deslocar uma peça, à direita ou esquerda, assim que tocava a construção (Figura 7). Esta inovação se deu ao final da Sessão1, com P1 consciente do seu efeito, pois no jogo seguinte iniciou-se a diferenciação de três esquemas de deslocamento (Figura 8): de um segmento de peça sob um segmento de outra (esquema

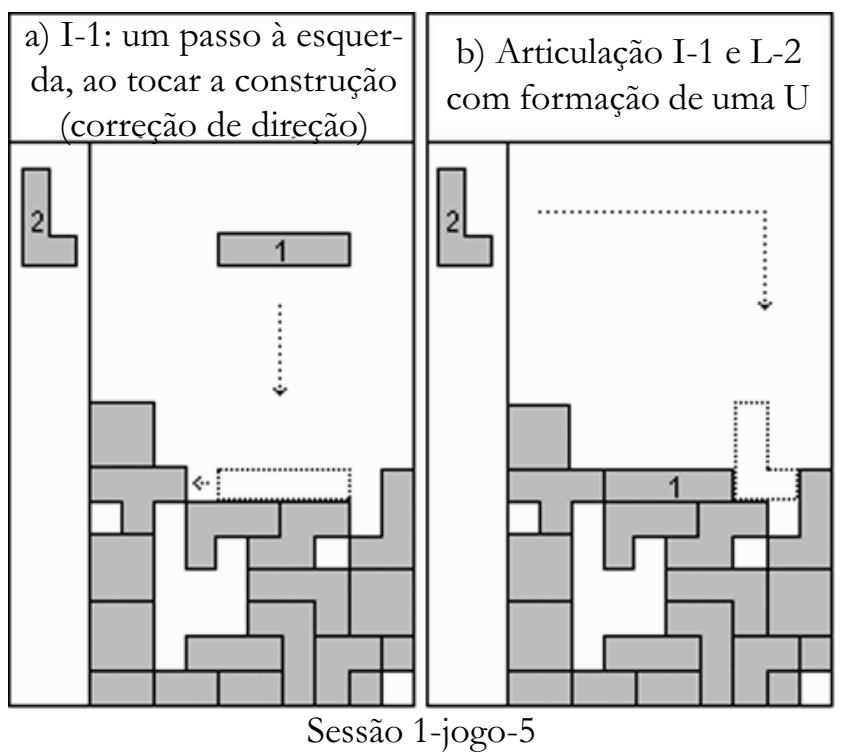

Figura 7. Deslocamento de uma peça, à esquerda ou direita, quando toca a construção.
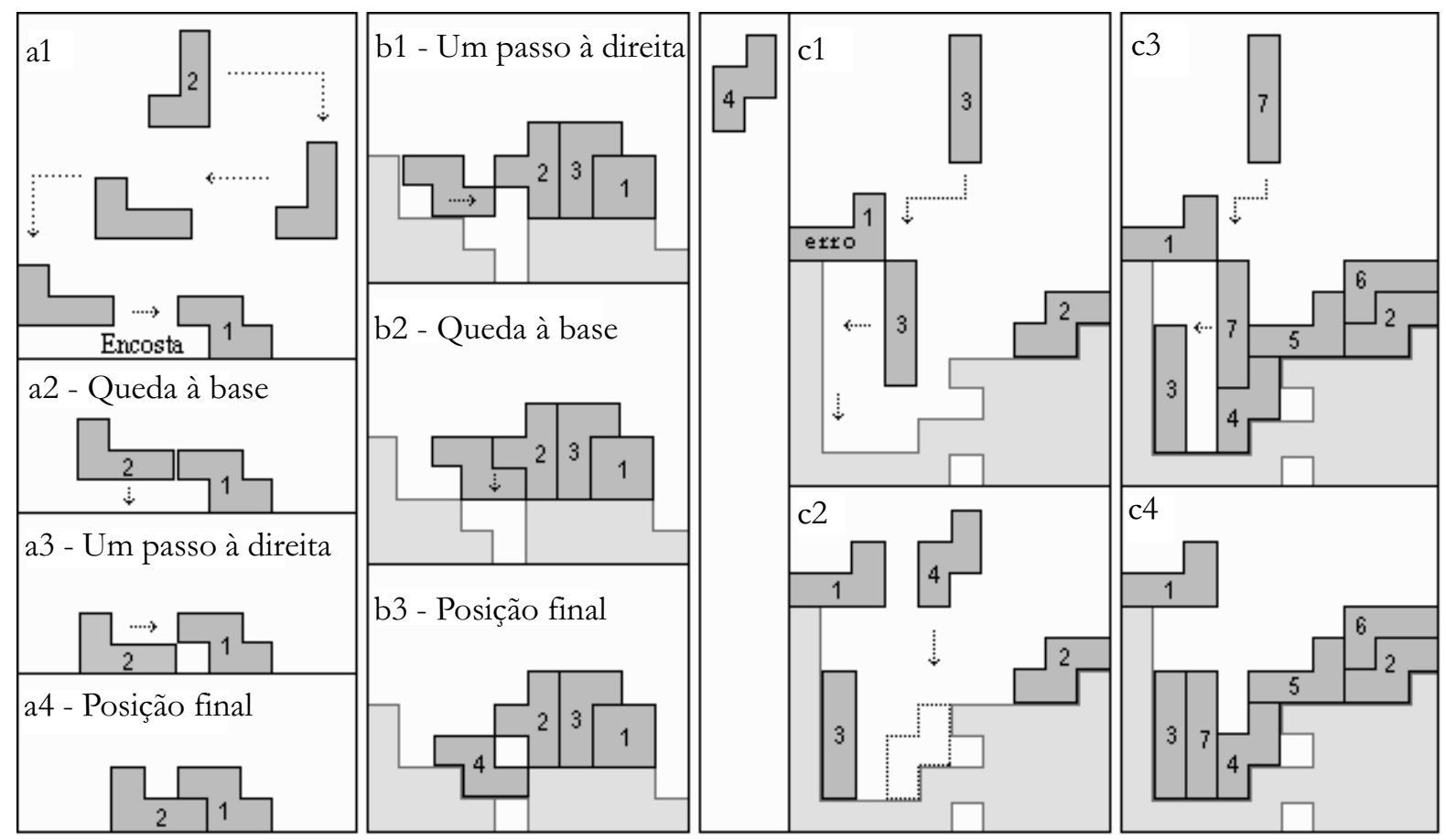

a) Sessão 2 - jogo 1: deslocamento de um segmento de peça sob um segmento de outra

b) Sessão 2 - jogo 2: deslocamento de uma peça sob um segmento de outra

c) Sessão 3- jogo 1: deslocamento de uma peça sob outra

Figura 8. Diferenciação de procedimentos compensatórios de erros. integrador de/com peça dentada), de uma peça sob um segmento de outra e de uma peça sob outra (dois esquemas compensatórios de erros que haviam gerado áreas vazadas).

\section{Evolução dos Modelos Mentais de Objetivo e do Fazer}

Com as melhorias descritas, P1 avançou para linhas compostas em adição às unitárias. Solidariamente, evoluíram tanto os modelos mentais do objetivo e do fazer, como a compreensão do jogo. Compor linha(s) sempre implica construir um retângulo, variando sua altura. Até o início da sessão-3, o objetivo representado (retângulo) convergia com o modelo do proceder, o que se traduziu em construçês planas, retangulares - com nivelamento da superfície por encaixe horizontal de peças, em especial as I e T (Figura 9a) — e se exprimiu nas concepções de P1:

\section{"Não pode deixar subir... deixar a montagem o mais baixa possível ... por a pecinha mais alta na horizontal." (1 a auto-avaliação, após sessão 1).}

“... Deixar o mais plano possivel em cima ... o que vier fica mais fácil de encaixar ... quando você se concentra em uma linha só, é mais fácil se perder... é mais fácil tentar fazer várias linhas, porque quando aparece aquela comprida tem como ajeitar tudo." (colocá-la na horizontal, nivelando a superfície) (2a auto-avaliação). 


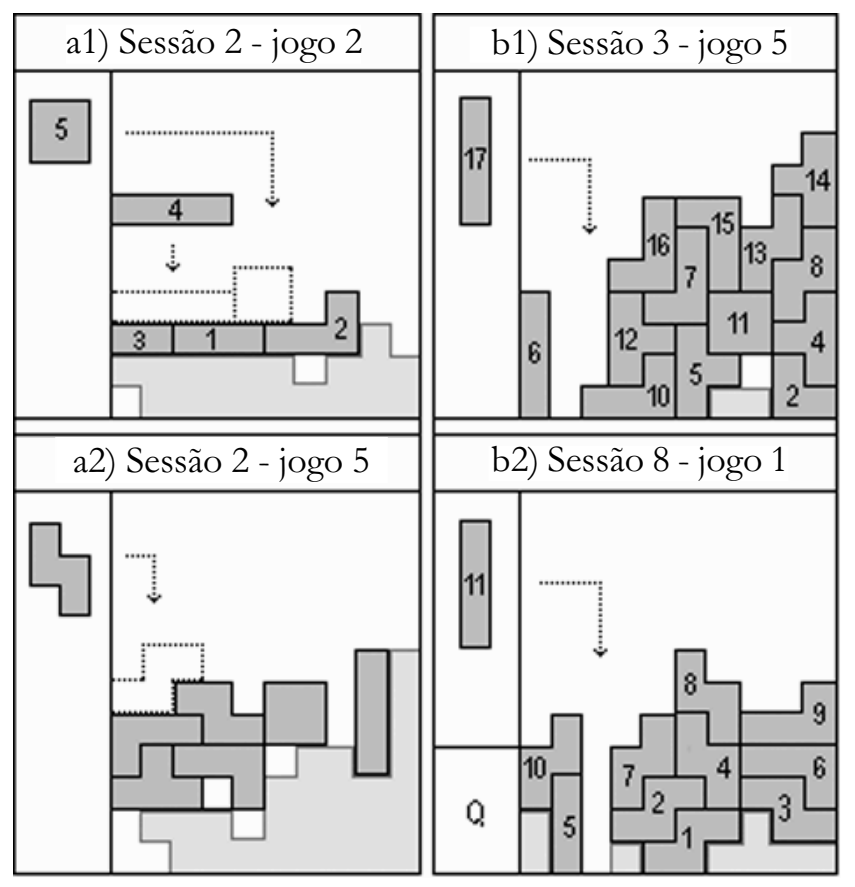

a) Primeiro modelo do como faz̧er: construções retangulares, com nivelamento de sua superfície

b) Segundo modelo do como faz̧er: construções piramidais e em degraus

Figura 9. Evolução dos modelos mentais do como fazer.

Logo, antes de constituírem novos objetivos, as construções compostas surgiram como estratégia para manter a construção nivelada/retangular. Mas, no lidar com várias linhas e já na sessão3 , as construções foram ganhando aparência dentada e a própria concepção do fazer (modelo) foi se alterando para construções piramidais/em degraus(Figura 9b):

“... Desconsidero que devia me preocupar com a horizontalidade ... manter retinho. Não é bom ... é bom deixar de forma que, qualquer pecinha que cair, você vai conseguir encaixar ... quando muitas estão com mesma altura fica difícil encaixar as que vêm ... seria formar uma pirâmide... uma escadinha, com espaço para todo tipo de ocupação, nos dois lados.” (3 auto-avaliação)

Uma ou mais linhas, o objetivo sempre exigia composição retangular. Mas, no fazer, o melhor tornouse uma construção dentada, refletindo um plano amplo que abrangia o presente (peça ativa-construção), o futuro imediato e conhecido (peça seguinte), como um futuro distante e incerto, já que P1 previa alocação para quaisquer peças (possíveis abstratos). Sua transição para construções piramidais/em degraus e seu uso espontâneo de termos precisos - horizontalidade, retinho vs pirâmide e escada atestaram a crescente interação entre seu fazercompreender, bem como consciência do seu próprio saber.
De toda esta evolução, emergiu outro procedimento compensatório: o resgate de áreas ou colunas bloqueadas (linhas incompletas) por meio de encaixes seletivos (Figura 10). Reabrir coluna(s) implicava completar e eliminar a(s) linha(s) que bloqueava(m) seu acesso (objetivo-meio), o que exigia minimizar ou não fazer sobreposição de peças em tal (ais) coluna(s). Assim, os encaixes seletivos supunham inferências e deduções encadeadas, representações mais

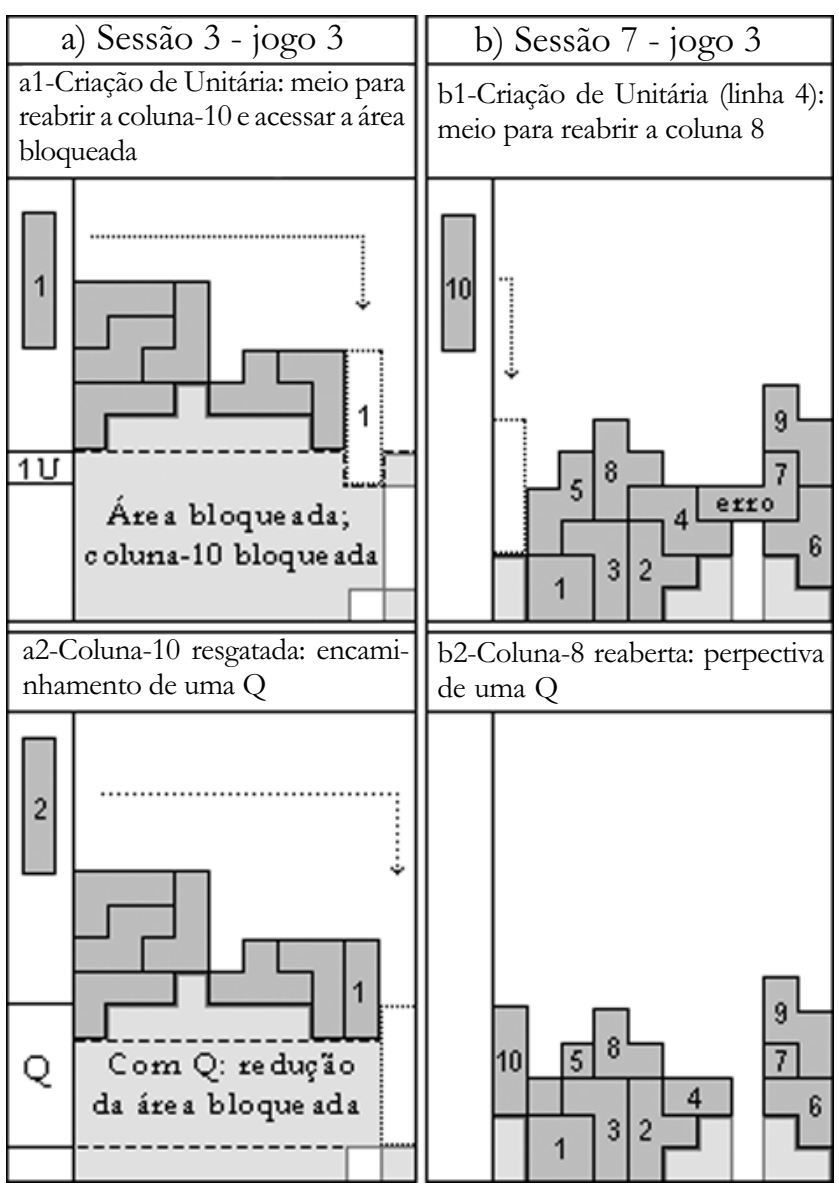

Figura 10. Procedimento de encaixes seletivos no resgate de colunas e áreas bloqueadas.

móveis, como planificação e articulações mais elaboradas. A ação de resgate traduziu uma resignificação das montagens incompletas (não mais vistas como produções perdidas) e das próprias ações construtivas, já que finalizar linha(s) desdobrou-se em um objetivo instrumental, atestando maior mobilidade entre meios e fins.

Este último procedimento ampliou a rejeição das hipóteses sobre construções dialéticas. Além de construções iniciais com mais articulações do que o previsto, ocorreram interdependências mais abrangentes. Previu-se coordenação apenas entre presente (peça atual-construção) e futuro imediato (peça seguinte). Porém, no todo de sua resolução, P1 abarcou interdependências entre o presente, o futuro 
imediato, o passado próximo (esquemas corretivos, com compensação de erros), um futuro indefinido (encaixes com abertura para quaisquer peças) e um passado mais remoto (resgate de áreas bloqueadas).

\section{Erros no processo resolutivo}

Os erros se enquadraram em 6 categorias: 1) Representação inadequada da correspondência peça-espaço; 2) Peça em direção errada; 3) Desarticulação peça atualseguinte-totalidade; 4) Justaposição de peças: também por desarticulação peça atual-seguinte-totalidade, sobressaiu sua ligação inicial com compreensão insuficiente do Tetris e, em todos os jogos, com sua velocidade maior, em especial no final deles; 5) Condutas planificadas, mas não finalizadas a contento; 6) Centração em um objetivo (unitária ou dupla) que impedia a antecipação e consecução de um outro maior (triplas e quádruplas).

Mesmo com o avanço resolutivo, estes vários erros ocorreram até a última sessão, mas em menor número e com significado diferente. Nos primeiros jogos, refletiam saberes difusos e se configuraram erros de Nível-I (justaposições e sincretismo). Com as pausas, muitos se tornaram percebidos de pronto e se revelaram construtivos, impulsionando melhorias. Constituíram erros de Nível-II, mais ligados a soluções empíricas e retroações do que a inferências e antecipações. Com os esquemas compensatórios e pré-corretivos, a separação entre os modelos de objetivo e do fazer, e o resgate das construções incompletas, os erros se configuraram do Nível-III, pois se deram num contexto de compreensão e resolução consistente do Tetris. Mesmo as justaposições, no final de todos os jogos, deixaram de denotar conhecimento genérico e insuficiente, para exprimir uma condição (rapidez do jogo) irrelevante do ponto de vista do compreender e saber executar o Tetris.

\section{Funcionamento cognitivo na resolução do Tetris}

Subjacente aos esquemas procedurais e conceituais, revelou-se a equilibração com sua regulação por feedbacks positivos: êxitos fortaleceram avaliações, antecipações, précorreções e compensações; da consolidação e articulação destes esquemas resultou o resgate de áreas bloqueadas. Também, regulação por feedbacks negativos: erros apreendidos levaram à modificação de esquemas, tal como na diferenciação dos deslocamentos sob, cuja composição levou aos esquemas compensatórios. Por sua vez, procedimentos mais complexos formados a partir dos elementares atestaram a equilibração horizontal interesquemas, enquanto a integração dos vários esquemas em uma totalidade (sistema de resolução do Tetris) implicou a equilibração vertical (Piaget, 1975/1976).

De início, esquemas geradores de obstáculos temporários (Inhelder, 1992/1996; Inhelder \& Caprona, 1992/1996a; 1992/1996b) restringiram o equilíbrio vertical. Um exemplo foi a falsa necessidade de construções retangulares, com superfície nivelada. Sua superação adveio da formação de superfícies irregulares quando da criação de linhas triplas e quádruplas, com vários efeitos: descoberta de uma arquitetura que favorecia encaixes bem-sucedidos (abstrações empíricas, feedback positivo, controle ascendente); conflito entre constatações e modelo do fazer (construção retangular que exercia controle descendente sobre o fazer); resignificação do modelo retangular, por controle ascendente derivado das ações e seus efeitos; resignificação dos esquemas executivos e descarte do nivelamento das construções, o que contribuiu na criação do resgate de áreas incompletas bloqueadas (Inhelder \& Cellérier, 1992/1996; Piaget, 1974/ 1978a, 1974/1978b, 1980/1996). Destas reelaborações advieram: generalização dedutiva quanto às construções piramidais/em degraus como modelo mais eficaz de execução, no qual os vários procedimentos resolutivos se tornaram interdependentes (equilibração vertical); separação entre meios (fazer) e fins (objetivo), entre modelo do fazer (piramidal) e o do objetivo (construção retangular); compreensão ampliada do Tetris (Inhelder \& Cellérier, 1992/1996).

Toda esta evolução de P1 sustentou-se em pausas freqüentes que garantiam análise e tomadas de consciência, com reconstruções do fazer-compreender derivadas da dinâmica da equilibração/abstrações reflexionantes e dos controles descendente/ascendente que, com resignificação das ações e dos seus efeitos, permitiam novas interdependências (Inhelder \& Cellérier, 1992/1996; Piaget, 1974/1978a, 1974/ 1978b, 1975/1976, 1980/1996).

O domínio final do Tetris por P1 revelou um sistema resolutivo com cinco níveis de interdependência: presente (peça atual-construção); futuro imediato (peça atualseguinte-construção); passado imediato (correções por deslocamentos sob); futuro distante (construções piramidais que previam encaixes de quaisquer peças) e passado distante (resgate de áreas incompletas). Ao conjugar o que ocorria no jogo, o que estava por vir e o que já fora, P1 mostrou compreensão articulada do Tetris. Neste contexto, os erros se configuraram possíveis do sistema, evitáveis por antecipações e planejamento, e resgatáveis por ações compensatórias. Ao tomar suas idéias sobre o jogo como objeto de reflexão, P1 revelou um plano de ação metacognitivo (Piaget, 1977/1995) na interação com o Tetris.

Tendo iniciado com soluções e erros mais elementares do que o hipotetizado para um sujeito com pensamento formal e tendo constituído interdependências, iniciais e globais, mais abrangentes e complexas do que o previsto, ao resolver o Tetris, P1 refez o curso da evolução cognitiva, com progresso desdobrado até o patamar de suas estruturas cognitivas. 


\section{Considerações Finais}

Duas questões se destacam por sua significação teórica. De um lado, as condutas iniciais de P1 (possíveis analógicos; justaposições e elaborações sincréticas) se sobressaem por sua discrepância com o teoricamente esperado para um sujeito com pensamento formal. Elas configuram a extensão de achados com crianças para um adulto: o saber inicial ativado - genérico, sincrético e com particularidades justapostas - aos poucos é reconstruído em um conhecimento preciso e sintético (Saada-Robert, 1992/1996). O desdobrar da resolução de P1 traduziu esta transformação, indicando que um modo hipotético-dedutivo de pensar não se traduz em soluções imediatas deste nível diante de problemas novos.

Para Inhelder e Caprona (1992/1996a), as estruturas cognitivas são "...as condições de um progresso possível" (p. 20), o que explica o avanço de P1 até um nível formal de compreensão-resolução do Tetris. Mas, eles também caracterizam as estruturas como "...o conjunto dos possíveis de partida, que permite o desenvolvimento de procedimentos" (p. 20), o que leva, de volta, à questão das condutas elementares iniciais de P1.

Em estudo nacional sobre o raciocínio de universitários ao resolverem o jogo Senha (criação de possíveis), todos exibiram compreensão do jogo em nível operatório formal e, apesar de todos possuírem as estruturas cognitivas necessárias, alguns não dominaram os procedimentos exigidos para a solução (Ortega \& Queiroz, 1997). Os autores se reportam a Davis e Espósito (1990), para quem uma das possíveis significações do erro seria: o sujeito dispõe da estrutura cognitiva e do saber fazer para solucionar um problema, mas selecionou estratégias impróprias; neste caso, o erro não seria construtivo e a situação não envolveria construção de conhecimento, mas emprego ou aprimoramento de saberes já construídos. Esta interpretação não esclarece, de fato, a ocorrência do erro e antepõe-se à "transformação pragmática" do conhecimento geral em conhecimento específico, inerente à solução de problemas (Inhelder \& Caprona, 1992/1996a, p. 36). Contrariando Davis e Espósito, pelos dados aqui obtidos, mesmo sujeitos com pensamento formal não dispõem do saber fazer necessário no início da solução de um problema novo, sendo pouco razoável assumir que a solução resulte de simples aprimoramento de conhecimentos prévios. Os dados indicaram um saber fazer/compreender que foi fruto de (re)construção contextualizada, que se constituiu dentro da resolução e em função dela.

Para Piaget (1947/1977), o raciocínio hipotético-dedutivo opera mentalmente sobre proposições verbais (manipulação simbólica) e, no raciocínio concreto, operações mentais são desencadeadas a partir da manipulação de objetos. Contudo, a simplificação de um problema por meios figurativos, comum em adolescentes e adultos (Horak, 1990; Shama \& Dreyfus, 1994; Simon, 1982, citado em Inhelder \& Caprona, 1992/ 1996a, p. 36) mostra que a preferência, mesmo de adultos, não é pelos caminhos formais de solução. Estruturas hipotético-dedutivas de pensamento não implicam focar um problema apenas em termos proposicionais e a sua materialização (figuras, diagramas) sugere a busca de uma formatação que permita sua abordagem em termos de raciocínio mais concreto, eventualmente, como um passo prévio até a composição de uma solução formal.

Neste quadro, as condutas elementares constatadas na resolução do Tetris deixam de soar discrepantes, se for legítimo entendê-las como parte tanto deste percurso prévio, como da reconstrução de um conhecimento categorial geral em um conhecimento específico. Processos identificados na solução de jogos de computador apóiam esta idéia: evolução do ensaio-erro para diagramação do problema em busca de compreensão; análise de dados, antecipações, busca de regularidades e explicação das várias possibilidades (Horak, 1990). O domínio de tais jogos é também atribuído a descobertas indutivas: teste de hipóteses formuladas a partir do jogar; elaboração progressiva de estratégias e da compreensão do jogo (Greenfield, 1984/1988). A despeito do paralelo com a dinâmica das construções dialéticas, estas explicações omitem os processos dedutivos envolvidos na solução de problemas. Em uma síntese, pode-se pensar a resolução de problemas como implicando um movimento entre induções e deduções, o que é outro modo de reafirmar o duplo controle ascendente (indução)-descendente (dedução).

Esta síntese leva à segunda questão teoricamente relevante, e que diz respeito à natureza dialética, ou não, das construções da universitária estudada. Ao longo da resolução do Tetris, as elaborações de P1 foram entendidas como de cunho dialético, interpretação que se antepõe à visão de Piaget (1980/1996), para quem o pensamento e as construções cognitivas só se configuram dialéticos quando há alterações estruturais. No seu dizer, os sistemas cognitivos já construídos/equilibrados levam a inferências proposicionais que não transformam as estruturas que as possibilitam. Desta forma, a evolução de P1 teria resultado apenas de deduções viabilizadas por seu pensamento operacional formal.

Porém, quando se consideram as diferenças conceituais e procedurais ao início e final do estudo, fica difícil negar o caráter dialético da evolução de P1: seu percurso marcouse por um ir e voltar constante, com avanços procedurais 
repercutindo na compreensão do jogo e com alterações conceituais levando a reconstruções no fazer. Não se sustenta a idéia de um progresso resultante apenas de deduções e soluções mentais, pois foi gestado num contexto de efetiva solução de problema e não fora dele.

As micro-mudanças encontradas instigam novos estudos. Dado o dinamismo do Tetris que impõe dificuldades nos primeiros contatos do jogador, os possíveis analógicos iniciais, as justaposições e sincretismos refletem uma particularidade do sujeito estudado? Ou uma regularidade, um passo da resolução do Tetris por jogadores novatos, que independe do seu raciocínio ser concreto ou formal? Particularidade ou regularidade, as condutas elementares observadas significam defasagens no plano do pensamento formal, como ocorrem na formação do raciocínio operacional relativo às conservações (Piaget, 1947/1977)? Assim, justifica-se o estudo de mais sujeitos com pensamento hipotético-dedutivo, tendo em vista a relevância teórica da relação entre estruturas cognitivas e solução de problemas, entre conhecimento categorial geral e especificidade do conhecimento, pois se trata de questão que continua pedindo melhor compreensão.

\section{Referências}

Abreu, A. R. (1996). O jogo de regra no contexto escolar: Uma análise na perspectiva construtivista. Em Associação Nacional de Pesquisa e PósGraduação em Psicologia (Org.), Cadernos da ANPEPP. Resumos de Teses, Dissertações e outras Publicações no Brasil-1995, 4, 279.

Branco, A. U. (1998). Metodologia na pesquisa co-construtivista e abordagem microgenética para estudos dos processos de comunicação [Resumos]. Em Associação Nacional de Pesquisa e Pós-Graduação em Psicologia (Org.), Anais, VII Simpósio de Pesquisa e Intercâmbio Científico (p. 7). Gramado, RS: ANPEPP.

Brenelli, R. P. (1996). O jogo como espaço para pensar: A construção de noções lógicas e aritméticas. Campinas, SP: Papirus.

Brenelli, R. P. (1997). Jogos de regra na sala de aula e construção de noções operatórias [Resumos]. Em Sociedade Interamericana de Psicologia (Org.), Anais, XXVT Congresso Interamericano de Psicologia. Resumos (p. 385). São Paulo, SP: Sociedade Interamericana de Psicologia .

CDEXPERT. (1996). Revista CDEXPERT: 400 jogos para Windows (Vol. 1). Em. São Paulo: CDEXPERT.

Doolittle, J. H. (1995) Using riddles and interactive computer games to teach problem-solving skills [Versão eletrônica]. Teaching of Psychology, 22 (1), 3336. Retirado em 20/03/2001, de: http://SearchERIC.org/ericdb/ EJ507454.htm

Davis, C. \& Espósito, Y. J. (1990). Papel e função do erro na avaliação escolar. Cadernos de Pesquisa, 74, 71-75.

Emura, Y. (1996). Emlith Version 3.01E. Em 400 jogos para Windows (Vol.1). Revista CDEXPERT. São Paulo, SP: CDEXPERT. (Original publicado em 1993)

Greenfield, P.M. (1988). O desenvolvimento do raciocínio na era da eletrônica: Os efeitos da TV, computadores e videogames (C. Bonamine, Trad.). São Paulo: Summus. (Original publicado em 1984)

Hoff, M. S. (2001). Pensamento dialético e possiveis em um jogo computadorizado. Tese de Doutorado não-publicada, Instituto de Psicologia e Fonoaudiologia, Pontifícia Universidade Católica de Campinas. Campinas, SP.
Hoff, M. S. \& Wechsler, S. M. (2002). A prática de jogos computadorizados em um grupo de adolescentes. Estudos de Psicologia (Campinas, SP), 19(2), 5977.

Horak, V. M. (1990, abril). Students' cognitive styles and their use of problemsolving heuristics and metacognitive processes. [Versão eletrônica]. Trabalho apresentado no Annual Meeting of the National Council of Teachers of Mathematics, Salt Lake City, UT. Retirado em 20/03/2001, de bttp:// SearcbERIC.org/ericdb/ED347069.htm

Inhelder, B. (1996). Preâmbulo (E. Gruman, Trad.). Em B. Inhelder \& G. Cellérier (Orgs.), O desenrolar das descobertas da criança: Um estudo sobre as microgêneses cognitivas (pp. XI-XIV). Porto Alegre: Artes Médicas. (Original publicado em 1992)

Inhelder, B. \& Caprona, de D. (1996a). Rumo ao construtivismo psicológico: Estruturas? Procedimentos? Os dois “indissociáveis” (E. Gruman, Trad.). Em B. Inhelder \& G. Cellérier (Org.), O desenrolar das descobertas da criança: Um estudo sobre as microgêneses cognitivas (pp. 7-37). Porto Alegre: Artes Médicas. (Original publicado em 1992)

Inhelder, B. \& Caprona, de D. (1996b). Um percurso de pesquisa (E. Gruman, Trad.). Em B. Inhelder \& G. Cellérier (Orgs.), O desenrolar das descobertas da criança: Um estudo sobre as microgêneses cognitivas (pp. 38-79). Porto Alegre: Artes Médicas. (Original publicado em 1992)

Inhelder, B. \& Cellérier, G. (Orgs.) (1996). O desenrolar das descobertas da criança: Um estudo sobre as microgêneses cognitivas (E. Gruman, Trad.). Porto Alegre, RS: Artes Médicas. (Original publicado em 1992)

Johnson, J. E. (1987). Do you think you might be wrong? Confirmation bias in problem solving. [Versão eletrônica]. Arithmetic Teacher, 34(9), 13-16. Retirado em 20/03/2001, de bttp://SearchERIC.org/ericda/EJ351493.htm

Macedo, L. de (1980). Relações entre a ação e sua compreensão. Psicologia, 6(2), 1926.

Macedo, L. de (1993). Para uma psicopedagogia construtivista. Em E. S. de Alencar (Org.), Novas contribuições da psicologia cognitiva aos processos de ensino e aprendizagem (pp. 119-140). São Paulo: Cortez.

Macedo, L. de (1994). Para uma visão construtivista do erro no contexto escolar. Em L. de Macedo (Org.), Ensaios construtivistas (pp. 63-79). São Paulo: Casa do Psicólogo.

Macedo, L. de \& Barone, K. C. (1997). Oficina de psicopedagogia: O jogo como instrumento para o desenvolvimento cognitivo da criança [Resumos]. Em Sociedade Interamericana de Psicologia (Org.), Anais, XXVI Congresso Interamericano de Psicologia (pp. 383-384). São Paulo: Sociedade Interamericana de Psicologia .

Mandinach, E. B. (1984, Abril). Clarifying the "A" in CAI for learners of different abilities. Assessing the cognitive consequences of computer environments for learning. [Versão eletrônica]. Trabalho apresentado no Annual Meeting of the American Educational Research Association, New Orleans, LA. Retirado em 20/03/2001, de bttp://SearcbERIC.org/ericda/EJ250177.btm

Meira, L. (1994). Análise microgenética e videografia: Ferramentas de pesquisa em Psicologia Cognitiva. Temas em Psicologia, 3, 59-71.

Ortega, A. C., Alves, R. M. \& Rossetti, C. B. (1992). O possível e o necessário no jogo de senha de escolares da pré-escola à 4 a série do primeiro grau [Resumos]. Em Sociedade Brasileira de Psicologia (Org.), Resumos de Comunicações Cientificas, XXII Reunião Anual de Psicologia (p. 103). Ribeirão Preto, SP: Sociedade Brasileira de Psicologia.

Ortega, A. C. \& Queiroz, S. S. de (1997). O possível e o necessário no jogo da Senha de universitários [Resumos]. Em Sociedade Brasileira para o Progresso da Ciência (Org.), Anais, $49^{a}$ Reunião Anual da SBPC (p. 58). Belo Horizonte, SBPC.

Piaget, J. (1976). A equilibração das estruturas cognitivas: Problema central do desenvolvimento (M. M. dos S. Penna, Trad.). Rio de Janeiro: Zahar. (Original publicado em 1975)

Piaget, J. (1977). Psicologia da inteligência (N. C. Caixeiro, Trad.). Rio de Janeiro: Zahar. (Original publicado em 1947)

Piaget, J. (1978a). A tomada de consciência (E. B. de Souza, Trad.). São Paulo: Melhoramentos/EDUSP. (Original publicado em 1974)

Piaget, J. (1978b). Fazer e compreender (C. L. de P. Leite, Trad.). São Paulo: Melhoramentos/EDUSP. (Original publicado em 1974) 
Piaget, J. (1985). O possível e o necessário (Vol. 1): Evolução dos possíveis na criança (B. M. de Albuquerque, Trad.). Porto Alegre: Artes Médicas. (Original publicado em 1981)

Piaget, J. (1986). O possivel e o necessário (Vol. 2): Evolução dos necessários na criança (B. M. de Albuquerque, Trad.). Porto Alegre: Artes Médicas. (Original publicado em 1983)

Piaget, J. (1992). O possível, o impossível e o necessário: As pesquisas em andamento ou projetadas no Centro Internacional de Epistemologia Genética (L. B. Leite \& A. A. de Medeiros, Trads.). Em L. B. Leite (Org.), Piagete a Escola de Genebra (pp. 51-71). São Paulo: Cortez. (Original publicado em 1976)

Piaget, J. (1995). Abstração reflexionante: Relacões lógico-aritméticas e ordem das relaçöes espaciais (F. Becker \& P. B. G. da Silva, Trads.). Porto Alegre: Artes Médicas. (Original publicado em 1977)

Piaget, J. (1996). As formas elementares da dialética. (F. M. Luiz, Trad.). São Paulo: Casa do Psicólogo. (Original publicado em 1980)

Queiroz, S. S. de (1995). Tipificação de erros em um jogo de regras: Uma abordagem construtivista. Dissertação de Mestrado não-publicada, Curso de PósGraduação em Psicologia , Universidade Federal do Espírito Santo. Vitória, ES.

Rieber, L. P. (1996). Seriously considering play: Designing interactive learning environments based on the blending of microworlds, simulations and games [Versão eletrônica]. Educational Technology Research \& Development, 44(2), 43-58. Retirado em 20/03/2001 de http://it.coe.uga.edu/ /rieber/ play. btml
Saada-Robert, M. (1996). A construção microgenética de um esquema elementar. (E. Gruman, Trad.). Em B. Inhelder \& G. Cellérier (Orgs.), O desenrolar das descobertas da criança: Um estudo sobre as microgêneses cognitivas (pp. 107-126). Porto Alegre: Artes Médicas. (Original publicado em 1992)

Santos, C. C. dos (1998). O raciocínio de crianças no jogo de quatro cores em contexto psicogenético. Em Associação Nacional de Pesquisa e PósGraduação em Psicologia (Org.), Cadernos da ANPEPP. Resumos de Teses, Dissertações e outras Publicações no Brasil-1997, 6, 233.

Setton, R., Castro, R., Vetorazzo, E., Prandini, P. \& Garzaro, S. (1998, 13 de julho). Família digital: Computador vira artigo de primeira necessidade. ÉPOCA, 1(8), 1.

Shama, G. \& Dreyfus, T. (1994). Visual, algebraic and mixed strategies in visually presented linear programming problems [Versão eletrônica]. Educational Studies in Mathematics, 26(1), 45-70. Retirado em 20/03/2001 de bttp:// SearcbERIC.org/ericda/EJ487064.btm

Sobre as autoras

Miriam Schifferli Hoff é Psicóloga, Mestre em Psicologia Educacional e Doutora em Psicologia como Profissão e Ciência. Professora Titular (Psicologia do Desenvolvimento) da Faculdade de Psicologia da Pontifícia Universidade Católica de Campinas. Integrante do Laboratório de Avaliação e Medidas Psicológicas - LAMP/ PUC-Campinas, com atuação na área da cognição e pensamento lógico-matemático.

Solange Muglia Wechsler é Psicóloga, Mestre em Psicologia Escolar e Doutora em Psicologia Educacional. Professora Titular do Programa de Pós-Graduação em Psicologia da Pontifícia Universidade Católica de Campinas. Coordenadora do Laboratório de Avaliação e Medidas Psicológicas - LAMP/ PUC-Campinas, com atuação na área da cognição e criatividade. Pesquisadora do CNPq. 


\section{MESTRADO E DOUTORADO EM PSICOLOGIA DO DESENVOLVIMENTO}

2004

Se você é graduado em Psicologia, tem um bom domínio da língua inglesa e deseja se preparar para ser um pesquisador, professor universitário, ou mesmo um profissional de alta qualificação, o Programa de Pós-Graduação em Psicologia do Desenvolvimento da Universidade Federal do Rio Grande do Sul é o local que você procura. Desfrute de um ambiente acadêmico estimulante, onde alunos e professores convivem diariamente, com dedicação integral ao estudo e à pesquisa. Escreva-nos pedindo maiores informações.

INFORMAÇÕES E INSCRIÇÃO

UFRGS

UNIVERSIDADE FEDERAL

DO RIO GRANDE DO SUL

Instituto de Psicologia

PROGRAMA DE PÓS-GRADUAÇÃO EM PSICOLOGIA DO DESENVOLVIMENTO

Secretaria do PPG em Psicologia do Desenvolvimento - UFRGS

Rua Ramiro Barcelos, 2600, térreo Campus da Saúde

90035003 Porto Alegre RS Brasil

Fone: (51) $33165246 \quad$ Fax: (51) 33165473

http://www.psicologia.ufrgs.br

E-mail: ppgdesen@ufrgs.br 